\title{
Kinetic Resolution of \\ Mono- and Bicyclic Diels-Alder Adducts via Sharpless Asymmetric Dihydroxylation
}

\author{
Frank J.A.D. Bakkeren, Antonius J.H. Klunder, Binne Zwanenburg* \\ Department of Organic Chemistry, NSR Center for Molecular Structure, Design and Synthesis, \\ University of Nijmegen, Toernooiveld, 6525 ED Nijmegen, The Netherlands
}

\begin{abstract}
Simple mono- and bicyclic olefins, readily available by the Diels-Alder methodology, are subjected to osmium-catalyzed asymmetric dihydroxylation with the aim to achieve kinetic resolution of the Diels-Alder adducts. The stereoselectivity factor $s$ varies from 1.1 to 2.5 . An effective procedure is developed to reconvert the cis-vicinal diols into the corresponding alkenes.

Copyright 으 1996 Elsevier Science Ltd
\end{abstract}

\section{INTRODUCTION}

The Diels-Alder methodology for the synthesis of cyclohexenes and cyclohexene derived structures is one of the most versatile and widely used synthetic operations in organic chemistry. Innumerable natural product syntheses are based on this [4+2]-cycloaddition usually starting from relatively simple cycloadducts ${ }^{1}$. For a successful use of the Diels-Alder reaction cycloadducts in enantiopure form with the desired absolute configuration are of great importance. For this reason considerable effort is spent on asymmetric Diels-Alder cyclizations using chiral dienes or/and dienophiles, or chiral catalysts with variable results ${ }^{2}$. Optical resolution often is an alternative to achieve this goal. Especially enzymatic kinetic resolution has broadened the synthetic utility of simple Diels-Alder adducts. We recently showed that bicyclic ester 1, which is the Diels-Alder adduct of cyclopentadiene and fumaric diethyl ester, can conveniently be resolved using pig's liver esterase (PLE) 3 .

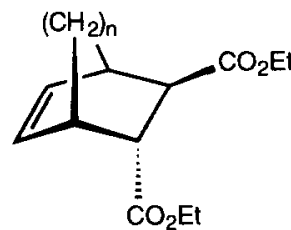

$1(\mathrm{n}=1)$

$2(n=2)$

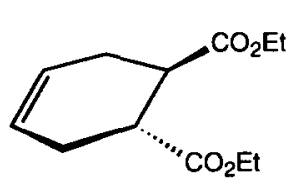

3

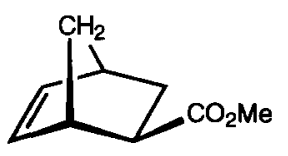

4<smiles>CC1C[C@@H](C(=O)O)[C@H]2C=CCC12</smiles>

$\mathbf{5}(\mathrm{n}=1, \mathrm{R}=\mathrm{Et})$ $6(\mathrm{n}=2, \mathrm{R}=\mathrm{Me})$

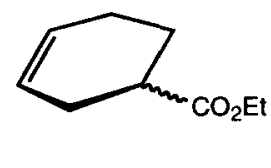

7

Fig. 1: Mono- and bicyclic Diels-Alder adducts 
However, this resolution appeared to be very dependent on the nature of the substrate and in fact failed for adducts 2,4 and 5 .

Recently, Sharpless and coworkers 4 published an improved procedure for the osmium-catalyzed asymmetric dihydroxylation of olefins applying a single set of reaction parameters for a wide range of olefins. The use of sulfonamide to accelerate the hydrolysis of the initially formed monoglycolate-osmate ester and employing phtalazine as a new ligand generally leads to cis-vicinal diols with enantiomeric purities up to 99\% 4.5 . This finding prompted us to study this osmium tetroxide-cinchona alkaloid system for the asymmetric cis-dihydroxylation of Diels-Alder cycloadducts 1-7. Since effective reconversion of cis-diols into the corresponding alkenes has been reported ${ }^{6}$, successful asymmetric dihydroxylation of the chiral Diels-Alder adduct 1-7 could be attractive for optical resolution of these cyclic olefins.

\section{RESULTS AND DISCUSSION}

\section{Strategy}

In determining which ligand should be used as the chiral auxiliary in the osmium tetroxide-catalyzed asymmetric cis-dihydroxylation ${ }^{4}$, we were confronted with the problem that our substrates 1-7 are cisdisubstituted olefins, which are the most difficult substrates in the dihydroxylation process ${ }^{7}$. The most widely applied chiral ligands are the pseudoenantiomers 1,4-bis(9-O-dihydroquinine) phtalazine ((DHQ) 2 PHAL) and 1,4-bis(9-O-dihydroquinidine) phtalazine ((DHQD) 2 PHAL), which for cis-olefins usually gave diols with rather low optical purities ${ }^{5 c, 8}$. Better results were obtained with 9-O-indolinylcarbamoyl dihydroquinidine (DHQDIND), an auxiliary especially developed for the asymmetric oxidation of cis-disubstituted olefins $^{9}$. However, this ligand seems to be effective only for non-cyclic $c i s$-olefins as the dihydroxylation of indene, the only cisolefin studied with the double bond incorporated in a ring system, gave the corresponding cis-diol with an enantiopurity of only $16 \% .10$

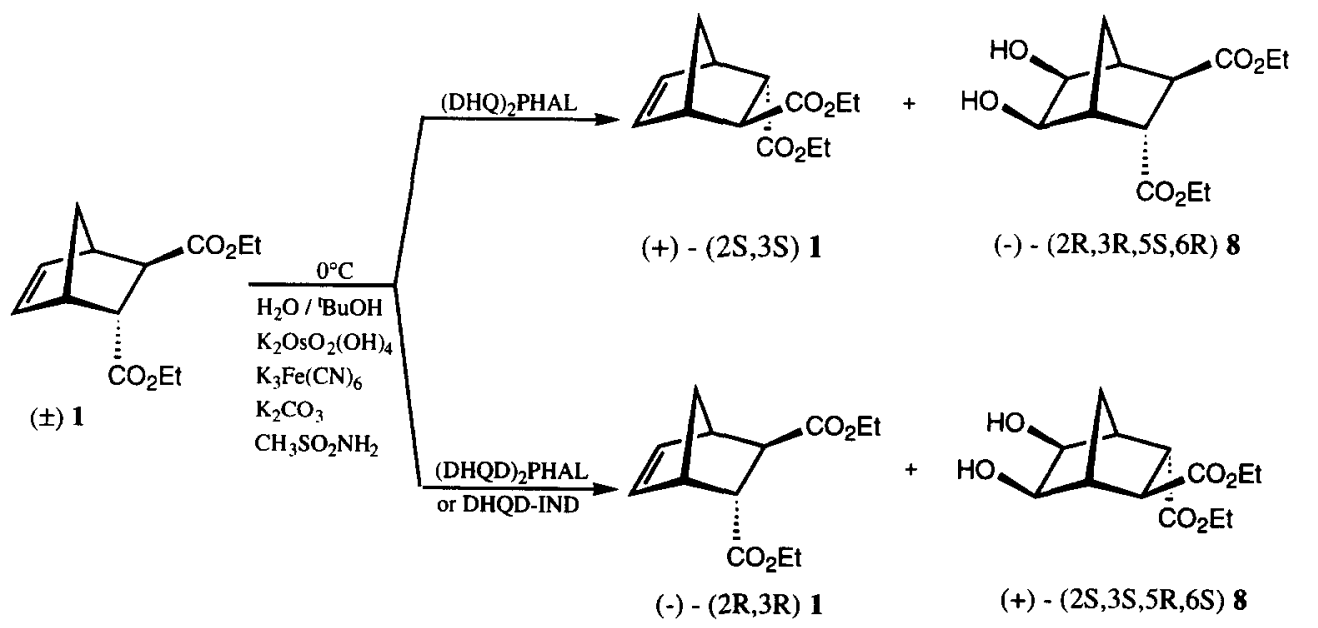

Scheme 1: Partial asymmetric dihydroxylation of 1 using different chiral ligands 
Attempts to improve the asymmetric dihydroxylation of cis-olefins by variation of the ligands only led to inductions comparable to those obtained with DHQD-IND, (DHQ) $)_{2} \mathrm{PHAL}$ and (DHQD) ${ }_{2} \mathrm{PHAL}$ ligands ${ }^{11}$. Recently, Takano et al. ${ }^{12}$ obtained satisfacory results for a meso-cyclic diene, using the latter two chiral auxiliaries. These results prompted us to first establish the effectiveness of all three ligands mentioned above in the asymmetric dihydroxylation of cis-alkenes 1-7. Diethyl bicyclo[2.2.1]hept-5-ene-trans-dicarboxylate 1 was selected as the model compound (Scheme 1).

Table 1: Kinetic resolution of racemic 1 via asymmetric dihydroxylation under different catalytic conditions using various cinchona alkaloid ligands.

\begin{tabular}{|c|c|c|c|c|c|c|c|c|c|}
\hline \multirow[b]{2}{*}{ Entry } & \multirow[b]{2}{*}{$\begin{array}{l}\text { Ligand } \\
(\mathrm{eq} .)^{\mathrm{a}}\end{array}$} & \multirow[b]{2}{*}{$\begin{array}{l}\text { time } \\
\text { (h) }\end{array}$} & \multirow[b]{2}{*}{$\begin{array}{c}\text { conv. } \\
(\%)\end{array}$} & \multicolumn{3}{|c|}{ recovered olefin 1} & \multicolumn{3}{|c|}{ obtained diol 8} \\
\hline & & & & $\begin{array}{c}{[\alpha]_{20}^{\mathrm{D}_{20}}} \\
\left(\mathrm{c}, \text { in } \mathrm{CHCl}_{3}\right)\end{array}$ & $\begin{array}{l}c y^{b} \\
(\%) \\
\end{array}$ & $\begin{array}{l}e e^{c} \\
(\%) \\
\end{array}$ & $\begin{array}{c}{[\alpha]_{20}^{\mathrm{D}_{20}}} \\
\left(\mathrm{c}, \text { in } \mathrm{CHCl}_{3}\right)\end{array}$ & $\begin{array}{l}c y^{b} \\
(\%)\end{array}$ & $\begin{array}{l}e e^{c} \\
(\%)\end{array}$ \\
\hline 1 & $(\mathrm{DHQ})_{2} \mathrm{PHAL} \quad(0.005)^{\mathrm{d}}$ & 51 & 72 & $+14.3(0.92)$ & 25 & 11 & $-0.7(1.22)$ & 55 & 5 \\
\hline 2 & $(\mathrm{DHQ})_{2} \mathrm{PHAL} \quad(0.01)$ & 20 & 73 & $+31.5(1.04)$ & 21 & 23 & $-1.2(1.05)$ & 48 & 9 \\
\hline 3 & $(\mathrm{DHQD})_{2} \mathrm{PHAL}(0.01)$ & 7.5 & 51 & $-25.5(1.05)$ & 48 & 20 & $+3.0(1.00)$ & 41 & 20 \\
\hline 4 & $(\mathrm{DHQD})_{2}$ PHAL $(0.01)$ & 16 & 96 & $-76.9(1.22)^{\mathrm{e}}$ & 3 & 76 & $+0.7(1.37)$ & 92 & 5 \\
\hline 5 & $(\mathrm{DHQD})_{2} \mathrm{PHAL}(0.05)^{\mathrm{f}}$ & 4 & 83 & $-70.0(0.96)$ & 14 & 55 & $+2.2(1.01)$ & 78 & 16 \\
\hline 6 & $(\mathrm{DHQD})_{2}$ PHAL $(0.1)^{\mathrm{f}}$ & 4 & 99 & $\mathrm{~g}$ & $\mathrm{~g}$ & $\mathbf{g}$ & g & $\mathrm{g}$ & $\mathrm{g}$ \\
\hline 7 & DHQD-IND & 8 & 36 & $-22.5(1.09)$ & 52 & 19 & $+4.3(0.99)$ & 31 & 31 \\
\hline 8 & DHQD-IND & 9 & 43 & $-31.7(1.27)$ & 55 & 25 & $+3.9(1.00)$ & 40 & 27 \\
\hline
\end{tabular}

${ }^{a}$ The amounts of the components necessary for the asymmetric dihydroxylation, other than the ligand, are described in the general procedure. The number of equivalents of the ligand used ( 0.01 equiv. (DHQ) 2 PHAL normally present in the AD-mix $\alpha$ and 0.01 equiv. (DHQD) ${ }_{2}$ PHAL in the AD-mix $\beta$ ) was taken relative to the initial amount of olefin. ${ }^{b}$ Isolated chemical yields. ${ }^{c}$ Enantiomeric excesses were determined by ${ }^{1} \mathrm{H}-\mathrm{NMR}$ experiments using $\mathrm{Eu}(\mathrm{hfc})_{3}$ as chiral shift reagent and correlating the measured optical rotations. ${ }^{\mathrm{d}}$ The amounts of all AD-reagents were halved, corresponding to 0.5 equiv. of $\mathrm{AD}$-mix $\alpha$. ${ }^{\text {This }}$ optical rotation is not entirely correct as the recovered olefin could not be purified further than $95 \%$ pure according to GC. ${ }^{\text {The relative amounts of both }}$ the ligand and the osmium reagent were increased five-fold (entry 5) and ten-fold (entry 6), respectively. 8 No attempts were made to obtain the olefin and diol separately. $\mathrm{g}_{0.02}$ equiv, is the recommanded relative amount for DHQD-IND ${ }^{9,13}$.

The results collected in Table 1 show that both the rate of the dihydroxylation and the optical yield are extremely low when only half of an equivalent of the $\mathrm{AD}$-mix is applied (Table 1, entry 1). Better results were obtained when the usual amount of the ligand ( 0.01 eq.) was used (entry 2$)$. However, the enantiopurity of the remaining olefin 1 is still low at a conversion of $73 \%$. Slightly better results were obtained with $(\mathrm{DHQD})_{2} \mathrm{PHAL}$ as a ligand (entries 3,4). This observation is a generally observed tendency 5 . After $7.5 \mathrm{~h} 50 \%$ conversion was reached and both recovered olefin 1 and the corresponding diol 8 were obtained in $20 \%$ ee. A nearly complete conversion was observed after $16 \mathrm{~h}$. Even at this high conversion the optical purity of recovered olefin 1 remained disappointingly low. A five- or a ten-fold increase of the combination of ligand $(\mathrm{DHQD})_{2} \mathrm{PHAL}$ and the osmium reagent relative to the other components of the AD-mix led to a much faster dihydroxylation of 1 but no improvement of the enantioselectivity was observed (entries 5,6). With DHQD-IND as the chiral auxiliary both the rate of dihydroxylation and the enantioselectivity are comparable with those observed for (DHQD) ${ }_{2} \mathrm{PHAL}$ (entries 7,8). 
These first results show that dihydroxylation of bicyclic alkenes such as 1 using AD-mix is possible albeit with modest enantioselectivity. Based upon the outcome of the above experiments the asymmetric dihydroxylation of mono- and bicyclic olefins 2-7 was investigated by taking one equivalent of AD-mix $\beta$ containing the relative amounts (DHQD $)_{2} \mathrm{PHAL}$ and $\mathrm{K}_{2} \mathrm{OsO}_{2}(\mathrm{OH})_{4}$ as recommended 4 .

\section{Synthesis}

Most substrates were readily available by a Diels-Alder reaction of the appropriate diene and dienophile $3,14,15$. Only the preparation of bicyclic mono-esters $4,5,6$ deserves some comment.

Reacting cyclohexadiene with ethyl acrylate afforded a 6:1 mixture of ethyl endo-and exobicyclo[2.2.2] octene carboxylates. The endo-isomer was obtained by selective iodolactonization of the corresponding mixture of endo/exo-acids 3,16 . After separation from the remaining exo-acid, the lactone was reduced with zinc to give the endo-carboxylic acid which on esterification with diazomethane afforded pure endo-ester 6. Unfortunately, the corresponding exo-ester could not be obtained pure and therefore is not included in this study. In a similar way pure exo-bicyclo[2.2.1 heptene ester 4 was prepared starting from a 3:1 endo/exo mixture of ethyl bicyclo[2.2.1] Jhept-5-ene 2 carboxylates. A sufficient amount of pure endo-ester 5 was obtained from the original endo/exo-mixture by column chromatography.

\section{Dihydroxylations}

The dihydroxylations of mono- and bicyclic olefins 1-7 were generally carried out until a conversion of about $50 \%$ had been reached. The progress of the reaction was followed by gas chromatography and the conversion determined as the quotient of the absolute amount of the produced diol and the sum of the absolute amounts of the diol and remaining olefin. Comparison of the analytical GC values with the isolated amounts of olefins and diols clearly showed that it was absolutely necessary to calibrate the GC response. This calibration was performed for olefin 1 and diol 8, resulting in two calibration lines with an excellent correlation factor $\left(R_{f}=0.99991\right)$ and linearity over the whole dynamic range. As expected the response factor for the olefin 1 is higher than for diol 8 , giving a quotient of 0.622 . It is noteworthy that upon extrapolation of the calibration curve of diol 8 there is a dead volume, which can only be explained by assuming that a fixed amount of the diol remains on the column. Decomposition is not likely as the peaks of the diols are perfectly sharp and symmetrical. For all sets of olefins and diols the degrees of conversion, as collected in Tables 1 and 2, were calculated with correction for the response difference and the dead volume of the diol determined for olefin 1 and diol 8. This is legitimate because of the close analogy of the olefins 1-7 and their corresponding diols (Table 2). The calculated degrees of conversion were in accordance with the isolated amounts of olefins and diols.

The structures of the diols 8-14 were established by ${ }^{1} \mathrm{H}-\mathrm{NMR}$ spectroscopy. For all bicyclic esters these dihydroxylations are completely diastereoselective as the result of steric blocking of one face of the olefinic unit either by an ester function or by an ethylene bridge, which is sterically more demanding than a methylene bridge. Hence, dihydroxylation of bicyclic esters 1,2,4,5 and 6 exclusively gave exo-diols 8,9,11,12 and 13 (Table 2).

Enantioselective dihydroxylation of the cyclohexene trans-diester 3 leads to just one pair of diastereomeric diols 10. Only for cyclohexene ester 7 a 2:1 mixture of diastereomeric diols 14 was formed. Apparently the 
ester function in $\mathbf{7}$ does not shield one of the olefinic faces to such an extent that complete diastereoselectivity is attained here.

The exo-structure of diols 8,9,11,12 and 13 could unambiguously be proven by ${ }^{1} \mathrm{H}-\mathrm{NMR}$ NOE studies on diol 13 which showed that there is a clear NOE-contact between the hydroxyl protons and $\mathrm{H}_{7, \text { syn }}$, the bridge

Table 2: Kinetic resolution of various olefins via asymmetric dihydroxylation applying one equivalent of AD-mix $\beta$.

\begin{tabular}{|c|c|c|c|c|c|c|c|c|c|c|}
\hline \multirow[b]{2}{*}{ Entry } & \multicolumn{6}{|c|}{ recovered olefin } & \multicolumn{4}{|c|}{ obtained diol } \\
\hline & $\begin{array}{l}\text { substrate }^{a} \\
\text { (racemic) }\end{array}$ & nr. & $\begin{array}{l}\text { time } \\
(\mathrm{h}) \\
\end{array}$ & $\begin{array}{c}\text { conv. } \\
(\%)\end{array}$ & $\begin{array}{l}c y^{b} \\
(\%)\end{array}$ & $\begin{array}{l}e^{c} \\
(\%)\end{array}$ & product $^{\mathrm{a}}$ & nr. & $\begin{array}{l}c y^{b} \\
(\%) \\
\end{array}$ & $\begin{array}{l}e e^{\mathrm{c}} \\
(\%) \\
\end{array}$ \\
\hline 1 & & 2 & 16 & 28 & 56 & 13 & & 9 & 22 & 11 \\
\hline 2 & & 2 & 24 & 36 & 49 & 11 & & 9 & 28 & 11 \\
\hline 3 & & 2 & 48 & 55 & 40 & 12 & & 9 & 42 & 10 \\
\hline 4 & & 1 & 7.5 & 51 & 48 & 20 & & 8 & 41 & 20 \\
\hline 5 & & 1 & 16 & 96 & 3 & 76 & & 8 & 92 & 5 \\
\hline 6 & & 3 & 6 & 23 & 66 & $31^{\mathrm{c}}$ & & 10 & 21 & $7^{d}$ \\
\hline 7 & & 3 & 8 & 69 & 28 & $41^{\mathrm{c}}$ & & 10 & 54 & $4^{d}$ \\
\hline 8 & & 6 & 20 & 57 & 37 & 10 & & 11 & 42 & 1.5 \\
\hline 9 & & 5 & 8 & 70 & 27 & 14 & & 12 & 60 & 9 \\
\hline 10 & & 4 & 8 & 55 & 37 & 35 & & 13 & 47 & 20 \\
\hline 11 & & 7 & 2 & 48 & e & e & & 14 & 38 & f \\
\hline 12 & $\mathrm{CO}_{2} \mathrm{Et}$ & 7 & 4 & 95 & $\mathrm{e}$ & e & & 14 & 78 & $\mathrm{f}$ \\
\hline
\end{tabular}

\footnotetext{
a Absolute configurations of the olefinic substrates were determined by comparing the sign of the measured optical rotation with the values reported in literature ${ }^{3,14,17}$. The absolute configuration of the corresponding diol is opposite to that of the olefin. $b_{\text {Isolated }}$

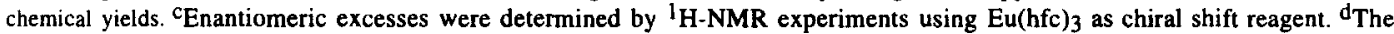
absolute configurations of olefin 3 and its corresponding diol are unknown. The drawn configurations were arbitrarily chosen. ${ }^{\mathrm{e}} \mathrm{No}$ accurate values were obtained due to purification problems. ${ }$ Both possible pairs of diastereomers of 14 were formed in a ratio of about $2: 1$.
} 
proton in syn-position with respect to both hydroxy moieties. Furthermore, proton $\mathrm{H}_{3}$,down has a strong NOEcontact with $\mathrm{H}_{5}$ and/or $\mathrm{H}_{6}$, the protons vicinal to the alcohol functions. Of the aforementioned diols diol $\mathbf{1 3}$ has the double bond sterically least hindered for endo-attack and yet no endo-positions for the hydroxy moieties have been found, allowing to state that diols 8,9,11,12 and 13 all have the exo-structure.

The data collected in Table 2 show that all substrates 1-7 undergo dihydroxylation with AD-mix $\beta$ although at rather low rates. The highest conversion rates are observed for the monocyclic olefins 3 and 7 . In the bicyclic series the experimental data clearly show that an increase of the bridge size slows down the dihydroxylation reaction (compare entries 1,2 and 8,9 ). These observations may be explained by the increased steric bulkiness at the convex face of the olefinic unit in going from cyclohexenes to bicyclo[2.2.1] heptenes to bicyclo[2.2.2]octenes. As expected, not much difference in rate is observed for the mono-and diester of the cycloalkenes.

The enantioselectivity observed for the asymmetric dihydroxylation reaction is rather disappointing in all cases. At about $50 \%$ conversion modest optical yields up to $41 \%$ for the remaining olefin (entries 6,7 and 10) and up to $20 \%$ for the newly formed diol (entries 4,10 ) were obtained. The stereoselectivity factor $s$, which correlates the conversion and the enantiomeric excess ${ }^{18}$, varies from 1.1 to 2.5 for entries $1-12$, and this is far too low to make these dihydroxylation reactions attractive for optical resolution purposes. The poor enantioselectivity observed here seems to be typical for kinetic resolutions via the asymmetric dihydroxylation methodology because thusfar only comparably low s-values were obtained $5,7 c, 19$. Better results were achieved sofar only with the double-helical fullerene $\mathrm{C}_{76^{20}}$.

For the structures 1-7 the enantiofacial differentation is apparently too small for effective chiral induction using AD-mix $\beta$. The stereogenic centres which cause the chiral dissymmetry of these cyclic olefins are probably too far away from the reaction centre ('meso-effect ${ }^{\prime}$ ). Interestingly however, there is some distinct influence of the configuration of these remote chiral centers on the transition state as illustrated by the significant differences in optical yields in the enantioselective dihydroxylation of the exo- and endo-bicyclo[2.2.1] ]heptene monoester (entries 9,10). Since these structures are conformationally rigid these results suggest that dihydroxylation of cycloalkene esters 1-7 using the AD-mix $\beta$ proceeds through a transition state which has only limited flexibility, confirming that the low enantioselectivity found for the substrates 1-7 is indeed caused by the so-called 'meso-effect'.

\section{Reconversion}

Although the asymmetric dihydroxylation of cycloalkene esters does not yet fulfil the requirements for a practical resolution of Diels-Alder adducts, we established an effective procedure for the reconversion of the

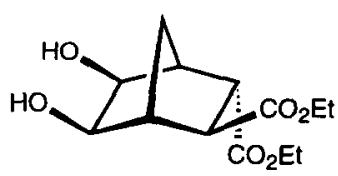

$(+)-(2 S, 3 S, 5 R, 6 S) 8$
1. $\mathrm{Ph}_{2} \mathrm{PCl}, \mathrm{I}_{2}$, imidazole toluene, reflux, $2 \mathrm{~h}$

2. $\mathrm{Zn}$, reflux, $1 \mathrm{~h}$ c. $y .=90 \%$

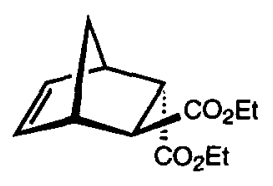

$(+)-(2 S, 3 S) 1$

Scheme 2: Olefination of cis-vicinal diol 
diol function to the alkene without loss of optical purity. Diol $(+)-8(e e=20 \%)$ which was chosen as the model compound, was treated with chlorodiphenyl phosphine and iodine ${ }^{6}$ to give the vicinal iodo diphenylphosphinate that was not isolated but immediately reductively eliminated with zinc to afford alkene (+)-1 in an excellent overall yield of $90 \%$. The optical purity of this alkene was fully retained thus no racemization had occurred during this eliminative process.

\section{Concluding remarks}

We demonstrated that the sequence of dihydroxylation and reductive reconversion of the diol moiety to the alkene function is an efficient chemical process which, in principle, would allow optical resolution of cycloalkenes produced by the Diels-Alder methodology. However, the enantioselectivity of the asymmetric dihydroxylation of a range of Diels-Alder adducts using $\mathrm{AD}$-mix $\beta$ is still too low to be of practical use. More effective osmium ligand complexes will have to be designed. Following the sequence as described above, alkene 1 was obtained with an optical purity of $20 \%$ starting from racemic 1.

Sofar no bicyclic diols either completely or partially resolved have been reported. With the exception of diols 12 and $13^{21}$ the resulting diols were not described previously.

\section{EXPERIMENTAL SECTION}

General _ Melting points were measured with a Reichert Thermopan microscope and are uncorrected. IR spectra were taken on a Perkin Elmer 298 infrared spectrophotometer. ${ }^{1} \mathrm{H}$ - and ${ }^{13} \mathrm{C}-\mathrm{NMR}$ spectra were recorded on a Bruker $\mathrm{AM}-400$ and a Bruker $\mathrm{AC}-100$, using $\mathrm{CDCl}_{3}$ as an internal standard. For mass spectra a double focussing VG 7070E mass spectrometer was used. Elemental analyses were performed on a Carlo Erba Instruments CHNS-O 1108 Elemental Analyzer. Optical rotations were measured with a Perkin Elmer 241 Polarimeter. GLC was conducted with a Hewlett-Packard HP5890II gas chromatograph, using a capillary column (HP1, 25m x $0.31 \mathrm{~mm} \times 0.17 \mu \mathrm{m})$. Flash chromatography was carried out at a pressure of $c a .1 .5$ bar, a column length of $15-30 \mathrm{~cm}$ and a column diameter of 1-4 cm, using Merck Kieselgel $60 \mathrm{H}$. All solvents used were dried and distilled according to standard procedures.

General procedure for the asymmetric dihydroxylation. - All dihydroxylation reactions were performed at a scale of $5 \mathrm{mmol}$ of olefin.

Three equivalents of $\mathrm{K}_{3} \mathrm{Fe}(\mathrm{CN})_{6}(4.94 \mathrm{~g}, 15 \mathrm{mmol}), 3.0$ equiv. of $\mathrm{K}_{2} \mathrm{CO}_{3}(2.07 \mathrm{~g}, 15 \mathrm{mmol}), 1.0$ equiv. of $\mathrm{CH}_{3} \mathrm{SO}_{2} \mathrm{NH}_{2}(0.48 \mathrm{~g}, 5 \mathrm{mmol}), 0.01$ equiv. of (DHQD) $)_{2} \mathrm{PHAL}(0.039 \mathrm{~g}, 0.05 \mathrm{mmol})$, and 0.002 equiv. of $\mathrm{K}_{2} \mathrm{OsO}_{2}(\mathrm{OH})_{4}(0.0037 \mathrm{~g}, 0.01 \mathrm{mmol})$ were dissolved in water $(25 \mathrm{~mL}, 5 \mathrm{~mL} / \mathrm{mmol})$ and $\mathrm{t}-\mathrm{BuOH}(25 \mathrm{~mL}, 5$ $\mathrm{mL} / \mathrm{mmol})$. This heterogeneous solution was cooled to $0^{\circ} \mathrm{C}$ and 1 equiv. of olefin $(5 \mathrm{mmol})$ was added to the suspension at once. After stirring the reaction mixture at $0^{\circ} \mathrm{C}$ for number of hours indicated in Table 1 and 2 the reaction was quenched by adding 12 equiv. of $\mathrm{Na}_{2} \mathrm{SO}_{3}(7.5 \mathrm{~g}, 60 \mathrm{mmol})$ and the reaction mixture was stirred for an additional hour at room temperature. Subsequently the reaction mixture was diluted with ethyl acetate (50 $\mathrm{mL}$ ) and extracted with water $(3 \mathrm{x})$. The aqueous fractions were then extracted with ethyl acetate $(3 \mathrm{x})$. The combined organic layers were concentrated in vacuo, the residue dissolved in diethyl ether and extracted with 
water ( $1 \mathrm{x}$ ) and brine (1x). Then the ether fraction was dried over $\mathrm{Na}_{2} \mathrm{SO}_{4}$ and concentrated in vacuo, resulting in a mixture of the starting olefin and the corresponding diol.

Diethyl exo,exo-5,6-dihydroxybicyclo[2.2.1] heptane-trans-2,3-dicarboxylate (8) The mixture of olefin $4(n=1)$ and diol 8 was separated by flash chromatography, starting with $n$-hexane:ethyl acetate $=5: 1$. After the olefin had eluted the eluent was changed to $n$-hexane:ethyl acetate $=1: 5$. Diol 8 was isolated as a white crystalline compound. m.p.: $37-39^{\circ} \mathrm{C}$. IR $\left(\mathrm{CCl}_{4}\right)$ : $\vee 3400(\mathrm{O}-\mathrm{H}), 1725(\mathrm{C}=\mathrm{O}) \mathrm{cm}^{-1}$. ${ }^{1} \mathrm{H}-\mathrm{NMR}(400 \mathrm{MHz}$, $\mathrm{CDCl}_{3}$ ): $\delta 4.16$ (overlapping q, ${ }^{3} \mathrm{~J}=7.0 \mathrm{~Hz}, 4 \mathrm{H}, \mathrm{O}-\mathrm{CH}_{2}-$ ), $3.85 \mathrm{~A}$ of $\mathrm{AB}\left(\mathrm{d},{ }^{3} \mathrm{~J}=5.7 \mathrm{~Hz}, 1 \mathrm{H}, \mathrm{H}_{5}\right.$ or $\mathrm{H}_{7}$ ), $3.76 \mathrm{~B}$ of $\mathrm{AB}\left(\mathrm{d},{ }^{3} \mathrm{~J}=5.7 \mathrm{~Hz}, 1 \mathrm{H}, \mathrm{H}_{5}\right.$ or $\left.\mathrm{H}_{7}\right), 3.49$ (br.s., $\left.1 \mathrm{H},-\mathrm{OH}\right), 3.39$ (br.s., $\left.1 \mathrm{H},-\mathrm{OH}\right), 3.19\left(\mathrm{t},{ }^{3} \mathrm{~J}=5.1 \mathrm{~Hz}, 1 \mathrm{H}\right.$, $\left.\mathrm{H}_{2}\right), 2.70\left(\mathrm{~d},{ }^{3} \mathrm{~J}=5.4 \mathrm{~Hz}, 1 \mathrm{H}, \mathrm{H}_{3}\right), 2.55\left(\mathrm{~d},{ }^{3} \mathrm{~J}=3.5 \mathrm{~Hz}, 1 \mathrm{H}, \mathrm{H}_{\mathrm{l}}\right), 2.48\left(\mathrm{~s}, 1 \mathrm{H}, \mathrm{H}_{4}\right), 1.86 \mathrm{~A}$ of $\mathrm{AB}(\mathrm{d}$, $2 \mathrm{~J}=11.0 \mathrm{~Hz}, \mathrm{H} 9), 1.42 \mathrm{~B}$ of $\mathrm{AB}\left(\mathrm{d},{ }^{2} \mathrm{~J}=11.0 \mathrm{~Hz}, \mathrm{Hg}\right), 1.28\left(\mathrm{t},{ }^{3} \mathrm{~J}=7.0 \mathrm{~Hz}, 3 \mathrm{H},-\mathrm{CH}_{3}\right), 1.26\left(\mathrm{t},{ }^{3} \mathrm{~J}=7.0 \mathrm{~Hz}, 3 \mathrm{H}\right.$, $\left.-\mathrm{CH}_{3}\right),{ }^{13} \mathrm{C}-\mathrm{NMR}\left(100 \mathrm{MHz}, \mathrm{CDCl}_{3}\right): \delta 173.7$ and $173.6(\mathrm{C}=\mathrm{O}), 73.2$ and $70.0\left(\mathrm{C}_{5}\right.$ and $\left.\mathrm{C}_{6}\right), 61.14$ and 61.06 $\left(\mathrm{O}-\mathrm{CH}_{2}\right), 48.3,46.4,46.1$ and $44.8\left(\mathrm{C}_{1}, \mathrm{C}_{2}, \mathrm{C}_{3}\right.$ and $\left.\mathrm{C}_{4}\right), 31.6\left(\mathrm{C}_{7}\right), 14.1\left(-\mathrm{CH}_{3}\right)$. EI/MS: $m / e(\%) 254(2$, $\mathrm{M}^{+}-\mathrm{H}_{2} \mathrm{O}$ ), $227\left(45, \mathrm{M}^{+} \mathrm{OEt}\right.$ ), $198\left(36, \mathrm{M}^{+}-\mathrm{COOEt}-\mathrm{H}\right), 82\left(100, \mathrm{C}_{5} \mathrm{H}_{6} \mathrm{O}^{+}\right)$. EI/HRMS: $\mathrm{m} / \mathrm{e} 254.11534$ (calc. for $\left.\mathrm{C}_{13} \mathrm{H}_{18} \mathrm{O}_{5}\left(\mathrm{M}^{+}-\mathrm{H}_{2} \mathrm{O}\right): 254.1154\right)$.

Diethyl exo,exo-5,6-dihydroxybicyclo[2.2.2]octane-trans-2,3-dicarboxylate (9) The mixture of olefin 2 and the corresponding diol was separated by flash chromatography, as described for 8 . The diol was obtained as a waxy compound. IR $\left(\mathrm{CCl}_{4}\right): \vee 3410(\mathrm{O}-\mathrm{H}), 1725(\mathrm{C}=\mathrm{O}) \mathrm{cm}^{-1} .{ }^{1} \mathrm{H}-\mathrm{NMR}\left(400 \mathrm{MHz}, \mathrm{CDCl}_{3}\right): \delta$ 4.16 (overlapping q, ${ }^{3} \mathrm{~J}=7.1 \mathrm{~Hz}, 4 \mathrm{H}, \mathrm{O}-\mathrm{CH}_{2}$ ), $3.97 \mathrm{~A}$ of $\mathrm{AB}\left(\mathrm{dd},{ }^{2} \mathrm{~J}=7.9 \mathrm{~Hz},{ }^{3} \mathrm{~J}=3.0 \mathrm{~Hz}, 1 \mathrm{H}, \mathrm{H}_{5}\right.$ or $\mathrm{H}_{6}$ ), 3.82 $B$ of $A B\left(d,{ }^{2} \mathrm{~J}=7.9 \mathrm{~Hz}, 1 \mathrm{H}, \mathrm{H}_{5}\right.$ or $\left.\mathrm{H}_{6}\right), 3.19\left(\mathrm{dd},{ }^{3} \mathrm{~J}=7.2 \mathrm{~Hz},{ }^{3} \mathrm{~J}=2.3 \mathrm{~Hz}, 1 \mathrm{H}, \mathrm{H}_{2}\right.$ or $\left.\mathrm{H}_{3}\right), 3.16$ (br.s., $1 \mathrm{H}$, $-\mathrm{OH}$ ), 3.07 (br.s., $1 \mathrm{H},-\mathrm{OH}$ ), 3.00 (d, ${ }^{3} \mathrm{~J}=7.2 \mathrm{~Hz}, 1 \mathrm{H}, \mathrm{H}_{2}$ or $\mathrm{H}_{3}$ ), 2.28 (br.s., $1 \mathrm{H}, \mathrm{H}_{1}$ or $\mathrm{H}_{4}$ ), 2.22-2.19 (m, $1 \mathrm{H}, \mathrm{H}_{1}$ or $\left.\mathrm{H}_{4}\right), 1.93-1.77\left(\mathrm{~m}, 2 \mathrm{H}, \mathrm{H}_{7}\right.$ and/or $\left.\mathrm{H}_{8}\right), 1.43-1.37\left(\mathrm{~m}, 1 \mathrm{H}, \mathrm{H}_{7}\right.$ or $\left.\mathrm{H}_{8}\right), 1.27\left(\mathrm{t},{ }^{3} \mathrm{~J}=7.1 \mathrm{~Hz}, 7 \mathrm{H}\right.$, $-\mathrm{CH}_{3}$ and $\mathrm{H}_{7}$ or $\left.\mathrm{H}_{8}\right) .{ }^{13} \mathrm{C}$-NMR ( $\left.100 \mathrm{MHz}, \mathrm{CDCl}_{3}\right): \delta 174.0$ and $173.6(\mathrm{C}=\mathrm{O}), 67.0$ and $64.5\left(\mathrm{C}_{5}\right.$ and $\left.\mathrm{C}_{6}\right)$, $61.1\left(\mathrm{O}-\mathrm{CH}_{2}-\right), 42.6$ and $41.7\left(\mathrm{C}_{2}\right.$ and $\left.\mathrm{C}_{3}\right), 34.7\left(\mathrm{C}_{1}\right.$ and $\left.\mathrm{C}_{4}\right), 17.6\left(\mathrm{C}_{7}\right.$ and $\left.\mathrm{C}_{8}\right), 14.1\left(-\mathrm{CH}_{3}\right)$. EI/MS: $m / e$ (\%) $287\left(100, \mathrm{M}^{+}+1\right), 269\left(37, \mathrm{M}^{+}+1-\mathrm{H}_{2} \mathrm{O}\right), 241\left(8, \mathrm{M}^{+}-\mathrm{OEt}\right), 223\left(11, \mathrm{M}^{+}-\mathrm{OEt}-\mathrm{H}_{2} \mathrm{O}\right), 96\left(20, \mathrm{C}_{6} \mathrm{H}_{8} \mathrm{O}^{+}\right)$. EL/HRMS: $m / e 286.1415$ (calc. for $\mathrm{C}_{14} \mathrm{H}_{22} \mathrm{O}_{6}\left(\mathrm{M}^{+}\right)$: 254.1416).

Diethyl syn-4,5-dihydroxycyclohexane-trans-1,2-dicarboxylate (10) The mixture of olefin 3 and the corresponding diol was separated by flash chromatography, as described for $\mathbf{8}$. The diol was obtained as a slightly yellow oil. IR $\left(\mathrm{CCl}_{4}\right): v 3410(\mathrm{O}-\mathrm{H}), 1720(\mathrm{C}=\mathrm{O}) \mathrm{cm}^{-1} .{ }^{1} \mathrm{H}-\mathrm{NMR}\left(400 \mathrm{MHz}, \mathrm{CDCl}_{3}\right): \delta 4.13(\mathrm{q}$, $\left.{ }^{3} \mathrm{~J}=7.1 \mathrm{~Hz}, 2 \mathrm{H}, \mathrm{O}-\mathrm{CH}_{2}-\right), 4.12\left(\mathrm{q},{ }^{3} \mathrm{~J}=7.1 \mathrm{~Hz}, 2 \mathrm{H}, \mathrm{O}-\mathrm{CH}_{2}-\right), 4.01$ (br.s., $\left.1 \mathrm{H}, \mathrm{H}_{4}\right), 3.70$ (ddd, ${ }^{3} \mathrm{~J}=10.1 \mathrm{~Hz}$, $\left.3 \mathrm{~J}=3.8 \mathrm{~Hz},{ }^{3} \mathrm{~J}=3.2 \mathrm{~Hz}, \mathrm{H}_{5}\right), 3.03\left(\mathrm{ddd},{ }^{3} \mathrm{~J}=12.0 \mathrm{~Hz},{ }^{3} \mathrm{~J}=11.2 \mathrm{~Hz},{ }^{3} \mathrm{~J}=4.0 \mathrm{~Hz}, 1 \mathrm{H}, \mathrm{H}_{2}\right), 2.74-2.67\left(\mathrm{~m}, 3 \mathrm{H}, \mathrm{H}_{1}\right.$ and $-\mathrm{OH}), 2.23 \mathrm{~A}$ of $\mathrm{AB}\left(\mathrm{dt},{ }^{2} \mathrm{~J}=14.1 \mathrm{~Hz},{ }^{3} \mathrm{~J}=4.0 \mathrm{~Hz}, 1 \mathrm{H}, \mathrm{H}_{3}\right), 2.03 \mathrm{~A}$ of $\mathrm{AB}\left(\mathrm{dt},{ }^{2} \mathrm{~J}=12.6 \mathrm{~Hz},{ }^{3} \mathrm{~J}=3.8 \mathrm{~Hz}, 1 \mathrm{H}\right.$, $\left.\mathrm{H}_{6}\right), 1.83 \mathrm{~B}$ of $\mathrm{AB}\left(\mathrm{q},{ }^{3} \mathrm{~J}=12.0 \mathrm{~Hz}, 1 \mathrm{H}, \mathrm{H}_{6}\right), 1.60 \mathrm{~B}$ of $\mathrm{AB}\left(\mathrm{ddd},{ }^{2} \mathrm{~J}=14.1 \mathrm{~Hz},{ }^{3} \mathrm{~J}=12.0 \mathrm{~Hz},{ }^{3} \mathrm{~J}=2.4 \mathrm{~Hz}, 1 \mathrm{H}\right.$, $\left.\mathrm{H}_{3}\right), 1.25\left(\mathrm{t},{ }^{3} \mathrm{~J}=7.1 \mathrm{~Hz}, 3 \mathrm{H},-\mathrm{CH}_{3}\right), 1.24\left(\mathrm{t},{ }^{3} \mathrm{~J}=7.1 \mathrm{~Hz}, 3 \mathrm{H},-\mathrm{CH}_{3}\right) .{ }^{13} \mathrm{C}-\mathrm{NMR}\left(100 \mathrm{MHz}, \mathrm{CDCl}_{3}\right): \delta 174.9$ and $173.8(\mathrm{C}=\mathrm{O}), 70.3$ and $67.9\left(\mathrm{C}_{4}\right.$ and $\left.\mathrm{C}_{5}\right), 60.83$ and $60.75\left(\mathrm{O}_{-} \mathrm{CH}_{2}-\right), 43.0$ and $38.4\left(\mathrm{C}_{1}\right.$ and $\left.\mathrm{C}_{2}\right), 32.9$ and $30.3\left(\mathrm{C}_{3}\right.$ and $\left.\mathrm{C}_{6}\right), 14.1\left(-\mathrm{CH}_{3}\right)$. EI/MS: $m / e(\%) 261\left(5, \mathrm{M}^{+}+1\right), 242\left(6, \mathrm{M}^{+}-\mathrm{H}_{2} \mathrm{O}\right), 216\left(50, \mathrm{M}^{+}+1-\mathrm{OEt}\right)$, $197\left(86, \mathrm{M}^{+}-\mathrm{OEt}-\mathrm{H}_{2} \mathrm{O}\right), 188\left(55, \mathrm{M}^{+}+1-\mathrm{COOEt}\right), 29\left(100, \mathrm{CH}_{3} \mathrm{CH}_{2}{ }^{+}\right)$. EL/HRMS: $m / e 242.11549$ (calc. for $\left.\mathrm{C}_{12} \mathrm{H}_{18} \mathrm{O}_{5}\left(\mathrm{M}^{+}-\mathrm{H}_{2} \mathrm{O}\right): 242.1154\right)$. 
Methyl exo,exo-5,6-dihydroxybicyclo[2.2.2]octane-endo-2-carboxylate (11) The mixture of olefin 6 and the corresponding diol was separated by flash chromatography, starting with n-hexane:ethyl acetate $=10: 1$. After the olefin had eluted the eluent was changed to pure ethyl acetate. The diol was obtained as a yellowish oil. IR $\left(\mathrm{CCl}_{4}\right): \vee 3390(\mathrm{O}-\mathrm{H}), 1725(\mathrm{C}=\mathrm{O}) \mathrm{cm}^{-1} .{ }^{1} \mathrm{H}-\mathrm{NMR}\left(400 \mathrm{MHz}, \mathrm{CDCl}_{3}\right): \delta 3.92\left(\mathrm{~s}, 2 \mathrm{H}, \mathrm{H}_{5}\right.$ and $\mathrm{H}_{7}$ ), 3.69 (s, 3H, $-\mathrm{O}-\mathrm{CH}_{3}$ ), 2.87 (br.s., $\left.1 \mathrm{H},-\mathrm{OH}\right), 2.85$ (br.s., $\left.1 \mathrm{H},-\mathrm{OH}\right), 2.70-2.65\left(\mathrm{~m}, 1 \mathrm{H}, \mathrm{H}_{2}\right), 2.0$ $1.2(\mathrm{~m}, 8 \mathrm{H}) .{ }^{13} \mathrm{C}-\mathrm{NMR}\left(100 \mathrm{MHz}, \mathrm{CDCl}_{3}\right): \delta 175.9(\mathrm{C}=\mathrm{O}), 67.3$ and $64.6\left(\mathrm{C}_{5}\right.$ and $\left.\mathrm{C}_{6}\right), 51.8\left(\mathrm{O}_{-} \mathrm{CH}_{3}\right), 40.2$ $\left(\mathrm{C}_{2}\right), 34.3$ and $30.8\left(\mathrm{C}_{1}\right.$ and $\left.\mathrm{C}_{4}\right), 25.5\left(\mathrm{C}_{3}\right), 18.2$ and $17.3\left(\mathrm{C}_{7}\right.$ and $\left.\mathrm{C}_{8}\right)$. EI/MS: $m / e(\%) 200\left(3, \mathrm{M}^{+}\right), 182$ $\left(29, \mathrm{M}^{+}-\mathrm{H}_{2} \mathrm{O}\right), 168\left(51, \mathrm{M}^{+}-\mathrm{CH}_{3} \mathrm{OH}\right), 150\left(33, \mathrm{M}^{+}-\mathrm{CH}_{3} \mathrm{OH}-\mathrm{H}_{2} \mathrm{O}\right), 96\left(100, \mathrm{C}_{6} \mathrm{H}_{8} \mathrm{O}^{+}\right)$. EI/HRMS: $m / e$ 200.10490 (calc. for $\mathrm{C}_{10} \mathrm{H}_{16} \mathrm{O}_{4}\left(\mathrm{M}^{+}\right): 200.1049$ ).

Ethyl exo,exo-5,6-dihydroxybicyclo[2.2.1]heptane-endo-2-carboxylate (12) The mixture of olefin $\mathbf{5}$ and the corresponding diol was separated by flash chromatography, starting with $\mathrm{n}$-hexane:ethyl acetate $=5: 1$. After the olefin had eluted the eluent was changed to pure ethyl acetate. The diol was obtained as a white solid. m.p.: $63-66^{\circ} \mathrm{C}\left(66-67^{\circ} \mathrm{C}^{21}\right)$. IR $\left(\mathrm{CCl}_{4}\right)$ : $\vee 3390(\mathrm{O}-\mathrm{H}), 1730(\mathrm{C}=\mathrm{O}) \mathrm{cm}^{-1} .{ }^{1} \mathrm{H}-\mathrm{NMR}\left(400 \mathrm{MHz}, \mathrm{CDCl}_{3}\right)$ : $\delta 4.14\left(\mathrm{q},{ }^{3} \mathrm{~J}=7.1 \mathrm{~Hz}, 2 \mathrm{H}, \mathrm{O}-\mathrm{CH}_{2}-\right), 3.79\left(\mathrm{~s}, 2 \mathrm{H}, \mathrm{H}_{5}\right.$ and $\left.\mathrm{H}_{7}\right), 3.20(\mathrm{~s}, 2 \mathrm{H},-\mathrm{OH}), 2.71\left(\mathrm{dt},{ }^{3} \mathrm{~J}=11.5 \mathrm{~Hz}\right.$, $\left.{ }^{3} \mathrm{~J}=5.0 \mathrm{~Hz}, 1 \mathrm{H}, \mathrm{H}_{2}\right), 2.46$ (br.s., $\left.1 \mathrm{H}, \mathrm{H}_{1}\right), 2.20\left(\mathrm{~d},{ }^{3} \mathrm{~J}=4.0 \mathrm{~Hz}, 1 \mathrm{H}, \mathrm{H}_{4}\right), 1.91\left(\mathrm{dd},{ }^{2} \mathrm{~J}=10.5 \mathrm{~Hz},{ }^{3} \mathrm{~J}=1.6 \mathrm{~Hz}\right.$, $1 \mathrm{H}, \mathrm{H}_{7}$ ), 1.70 (ddd, $2 \mathrm{~J}=13.2 \mathrm{~Hz}, 3 \mathrm{~J}=11.5 \mathrm{~Hz}, 3 \mathrm{~J}=5.0 \mathrm{~Hz}, 1 \mathrm{H}, \mathrm{H}_{3}$ ), 1.53 (ddd, $2 \mathrm{~J}=13.2 \mathrm{~Hz}, 3 \mathrm{~J}=5.3 \mathrm{~Hz}$, $\left.3 \mathrm{~J}=2.4 \mathrm{~Hz}, 1 \mathrm{H}, \mathrm{H}_{3}\right), 1.27\left(\mathrm{t},{ }^{3} \mathrm{~J}=7.1 \mathrm{~Hz}, 4 \mathrm{H},-\mathrm{CH}_{3}\right.$ and $\left.\mathrm{H}_{9}\right) .{ }^{13} \mathrm{C}-\mathrm{NMR}\left(100 \mathrm{MHz}, \mathrm{CDCl}_{3}\right): \delta 174.1(\mathrm{C}=\mathrm{O})$, 74.0 and $70.7\left(\mathrm{C}_{5}\right.$ and $\left.\mathrm{C}_{6}\right), 60.6\left(\mathrm{O}_{-} \mathrm{CH}_{2^{-}}\right), 46.5\left(\mathrm{C}_{2}\right), 43.7$ and $42.6\left(\mathrm{C}_{1}\right.$ and $\left.\mathrm{C}_{4}\right), 33.5\left(\mathrm{C}_{7}\right), 27.4\left(\mathrm{C}_{3}\right), 14.2$ (- $\left.\mathrm{CH}_{3}\right)$. EI/MS: $m / e(\%) 182\left(8, \mathrm{M}^{+}-\mathrm{H}_{2} \mathrm{O}\right), 155\left(27, \mathrm{M}^{+}-\mathrm{OEt}\right), 82\left(100, \mathrm{C}_{5} \mathrm{H}_{6} \mathrm{O}^{+}\right)$. EI/HRMS: $m / e 182.09430$ (calc. for $\mathrm{C}_{10} \mathrm{H}_{14} \mathrm{O}_{3}\left(\mathrm{M}^{+}-\mathrm{H}_{2} \mathrm{O}\right)$ : 182.0943).

Methyl exo,exo-5,6-dihydroxybicyclo[2.2.1]heptane-exo-2-carboxylate (13) The mixture of olefin 4 and the corresponding diol was separated by flash chromatography, starting with $n$-hexane:ethyl acetate $=3: 1$. After the olefin had eluted the eluent was changed to pure ethyl acetate. The diol was obtained as a white crystalline compound. m.p.: $49-52^{\circ} \mathrm{C}\left(50-53^{\circ} \mathrm{C}^{21}\right)$. IR $\left(\mathrm{CCl}_{4}\right): \vee 3400(\mathrm{O}-\mathrm{H}), 1730(\mathrm{C}=\mathrm{O}) \mathrm{cm}^{-1} .{ }^{1} \mathrm{H}-\mathrm{NMR}(400$ $\mathrm{MHz}_{\mathrm{CDCl}}$ ): $\delta 3.72$ (s, $2 \mathrm{H}, \mathrm{H}_{5}$ and $\mathrm{H}_{6}$ ), 3.68 (s, 3H, O-CH3), 3.40 (br.s., $1 \mathrm{H},-\mathrm{OH}$ ), 3.27 (br.s., $1 \mathrm{H}$, $\mathrm{OH}), 2.42\left(\mathrm{~s}, 1 \mathrm{H}, \mathrm{H}_{1}\right), 2.23-2.19\left(\mathrm{~m}, 2 \mathrm{H}, \mathrm{H}_{2}\right.$ and $\left.\mathrm{H}_{4}\right), 1.86 \mathrm{~A}$ of $\mathrm{AB}\left(\mathrm{dt},{ }^{2} \mathrm{~J}=13.2 \mathrm{~Hz},{ }^{3} \mathrm{~J}=5.0 \mathrm{~Hz}, 1 \mathrm{H}, \mathrm{H}_{3}\right.$ up $)$, $1.75 \mathrm{~A}$ of $\mathrm{AB}\left(\mathrm{d}, 2 \mathrm{~J}=10.8 \mathrm{~Hz}, 1 \mathrm{H}, \mathrm{H}_{7}\right.$ syn $), 1.40-1.34\left(\mathrm{~m}, 2 \mathrm{H}, \mathrm{H}_{3}\right.$ down and $\mathrm{H}_{7}$ anti). ${ }^{13} \mathrm{C}-\mathrm{NMR}(100 \mathrm{MHz}$, $\left.\mathrm{CDCl}_{3}\right): \delta 175.6(\mathrm{C}=\mathrm{O}), 73.81$ and $73.77\left(\mathrm{C}_{5}\right.$ and $\left.\mathrm{C}_{6}\right), 52.0\left(\mathrm{O}-\mathrm{CH}_{3}\right), 47.2\left(\mathrm{C}_{2}\right), 42.7$ and $41.8\left(\mathrm{C}_{1}\right.$ and $\left.\mathrm{C}_{4}\right)$, 29.8 and $29.0\left(\mathrm{C}_{3}\right.$ and $\left.\mathrm{C}_{7}\right)$. EI/MS: $m / e(\%) 186\left(1, \mathrm{M}^{+}\right), 168\left(38,\left(\mathrm{M}^{+}-\mathrm{H}_{2} \mathrm{O}\right), 154\left(100, \mathrm{M}^{+}-\mathrm{CH}_{3} \mathrm{OH}\right)\right.$. EI/HRMS: $m / e$ 186.08927 (calc. for $\mathrm{C}_{9} \mathrm{H}_{14} \mathrm{O}_{4}\left(\mathrm{M}^{+}\right)$: 186.0892 .

Ethyl syn-3,4-dihydroxycyclohexane-1-carboxylate (14) The mixture of olefin 7 and the corresponding diols were separated by flash chromatography, starting with $n$-hexane:ethyl acetate $=10: 1$. After the olefin had eluted the eluent was changed to $n$-hexane:ethyl acetate $=1: 3$. This resulted in the isolation of the diol as a colorless oil, which contained all four possible enantiomers as was indicated by NMR-experiments using $\mathrm{Eu}(\mathrm{hfc})_{3}$ as a chiral shift reagent. IR $\left(\mathrm{CCl}_{4}\right): v 3410(\mathrm{O}-\mathrm{H}), 1730(\mathrm{C}=\mathrm{O}) \mathrm{cm}^{-1}$. EI/MS: $m / e(\%) 188(1$, $\left.\mathrm{M}^{+}\right), 170\left(5, \mathrm{M}^{+}-\mathrm{H}_{2} \mathrm{O}\right), 159\left(2, \mathrm{M}^{+}-\mathrm{Et}\right), 143\left(20, \mathrm{M}^{+}-\mathrm{OEt}\right), 116\left(24, \mathrm{M}^{+}+1-\mathrm{COOEt}\right), 97\left(100, \mathrm{C}_{6} \mathrm{H}_{9} \mathrm{O}^{+}\right)$. 
Diethyl bicyclo[2.2.1]hept-5-ene-trans-2,3-dicarboxylate (1) A solution of diol $8(0.55 \mathrm{~g}, 2.0$ mmol) and imidazole $(0.55 \mathrm{~g}, 8.0 \mathrm{mmol})$ in toluene $(50 \mathrm{~mL})$ was heated under reflux, then chloro diphenylphosphine ( $0.86 \mathrm{~mL}, 4.8 \mathrm{mmol})$ was added. After 10 minutes iodine $(1.22 \mathrm{~g}, 4.8 \mathrm{mmol})$ was gradually added and the reaction mixture was heated under reflux for $2 \mathrm{~h}$. Subsequently, an excess of zinc powder was added at room temperature and the reaction mixture was heated under reflux for an additional hour. The reaction was stopped by filtration over celite, and the residue was washed with $3 \mathrm{~N} \mathrm{HCl}$ (aq.). The aqueous phase was extracted with ethyl acetate $(3 x)$. The organic fractions were washed with saturated aqueous $\mathrm{NaHCO}_{3}$-solution and brine, dried over $\mathrm{Na}_{2} \mathrm{SO}_{4}$ and concentrated in vacuo. Flash chromatography (n-hexane : ethyl acetate = 10:1) of the residue resulted in the isolation of 1 as a yellowish oil $(0.44 \mathrm{~g}, 90 \%)$. IR $\left(\mathrm{CCl}_{4}\right): 3070(\mathrm{C}-\mathrm{H}$, unsat.), $1730(\mathrm{C}=\mathrm{O}) \mathrm{cm}^{-1} .{ }^{1} \mathrm{H}-\mathrm{NMR}\left(400 \mathrm{MHz}, \mathrm{CDCl}_{3}\right): \delta 6.28\left(\mathrm{dd},{ }^{3} \mathrm{~J}=3.2 \mathrm{~Hz},{ }^{3} \mathrm{~J}=5.6 \mathrm{~Hz}, 1 \mathrm{H}, \mathrm{H}_{5}\right.$ or $\left.\mathrm{H}_{6}\right)$, $6.07\left(\mathrm{dd},{ }^{3} \mathrm{~J}=2.8 \mathrm{~Hz},{ }^{3} \mathrm{~J}=5.6 \mathrm{~Hz}, 1 \mathrm{H}, \mathrm{H}_{5}\right.$ or $\left.\mathrm{H}_{6}\right), 4.17\left(\mathrm{q},{ }^{3} \mathrm{~J}=7.0 \mathrm{~Hz}, 2 \mathrm{H}, 0-\mathrm{CH}_{2}-\right), 4.10\left(\mathrm{dq},{ }^{3} \mathrm{~J}=7.0 \mathrm{~Hz}\right.$, $\left.3 \mathrm{~J}=2.0 \mathrm{~Hz}, 2 \mathrm{H}, \mathrm{O}-\mathrm{CH}_{2-}\right), 3.37\left(\mathrm{t},{ }^{3} \mathrm{~J}=4.1 \mathrm{~Hz}, 1 \mathrm{H}, \mathrm{H}_{3}\right), 3.26\left(\mathrm{~s}, 1 \mathrm{H}, \mathrm{H}_{1}\right.$ or $\left.\mathrm{H}_{4}\right), 3.12\left(\mathrm{~s}, 1 \mathrm{H}, \mathrm{H}_{1}\right.$ or $\left.\mathrm{H}_{4}\right), 2.67$ (dd, $\left.{ }^{3} \mathrm{~J}=4.5 \mathrm{~Hz},{ }^{3} \mathrm{~J}=1.6 \mathrm{~Hz}, 1 \mathrm{H}, \mathrm{H}_{2}\right), 1.62 \mathrm{~A}$ of $\mathrm{AB}\left(\mathrm{d},{ }^{3} \mathrm{~J}=8.7 \mathrm{~Hz}, 1 \mathrm{H}, \mathrm{H}_{7}\right), 1.45 \mathrm{~B}$ of $\mathrm{AB}\left(\mathrm{dd},{ }^{3} \mathrm{~J}=8.7 \mathrm{~Hz}\right.$, $\left.{ }_{3} \mathrm{~J}=1.6 \mathrm{~Hz}, 1 \mathrm{H}, \mathrm{H}_{7}\right), 1.28\left(\mathrm{t},{ }^{3} \mathrm{~J}=7.0 \mathrm{~Hz}, 3 \mathrm{H},-\mathrm{CH}_{3}\right), 1.26\left(\mathrm{t},{ }^{3} \mathrm{~J}=7.0 \mathrm{~Hz}, 3 \mathrm{H},-\mathrm{CH}_{3}\right) .{ }^{13} \mathrm{C}-\mathrm{NMR}(100 \mathrm{MHz}$, $\left.\mathrm{CDCl}_{3}\right) \delta 174.4$ and $173.3(\mathrm{C}=\mathrm{O}), 137.5$ and $135.0\left(\mathrm{C}_{5}\right.$ and $\left.\mathrm{C}_{6}\right), 60.8$ and $60.5\left(\mathrm{O}_{-} \mathrm{CH}_{2}-\right), 47.9,47.7,47.2$ and $45.7\left(\mathrm{C}_{1}, \mathrm{C}_{2}, \mathrm{C}_{3}\right.$ and $\left.\mathrm{C}_{4}\right), 47.2\left(\mathrm{C}_{7}\right), 14.2\left(-\mathrm{CH}_{3}\right)$. EI/MS: $m / e(\%) 239\left(4, \mathrm{M}^{+}+1\right), 193\left(14, \mathrm{M}^{+}-\mathrm{OEt}\right)$, $173\left(34, \mathrm{M}^{+}-\mathrm{C}_{5} \mathrm{H}_{5}\right), 165\left(16, \mathrm{M}^{+}-\mathrm{COOEt}\right), 66\left(100, \mathrm{C}_{5} \mathrm{H}_{6}{ }^{+}\right)$. EI/HRMS: m/e 238.12055 (calc. for $\mathrm{C}_{13} \mathrm{H}_{18} \mathrm{O}_{4}$ $\left(\mathrm{M}^{+}\right):$238.1205).

\section{REFERENCES AND NOTES}

1. (a) Helmchen, G.; Goeke, A.; Kreisz, S.; Krotz, A.; Lauer, G.H.; Linz, G. Cyclopentanoid Natural Products via Asymmetric Diels-Alder Reactions. In Studies in Natural Products Chemistry, Vol. 8. Elsevier Science Publishers B.V.: Amsterdam, 1991; 139. (b) Pindur, U.; Lutz, G.; Otto, C. Chem. Rev., 1993, 93, 741. (c) Fringuelli, F.; Tatichi, A. Dienes in the Diels-Alder Reaction. Wiley: New York, 1990. (d) Desimo, G.; Tacconi, G.; Barco, A.; Pollini, G.P. Natural Products Synthesis through Pericyclic Reactions. In ACS Monograph Series, No. 180, 1983.

2. (a) Paquette, L.A. Asymmetric Synthesis, Vol. 3; Morrison J.D. Ed.; Academic Press: Orlando, 1984, Chapter 7. (b) Oppolzer, W. Angew. Chem., Int. Ed. Engl., 1984, 23, 876. (c) Trost, B.M.; O'Krongly, D.; Belletire, J.L. J. Am. Chem. Soc., 1980, 102, 7595. (d) Corey, E.J.; Ensley, H.E. J. Am. Chem. Soc., 1975, 97, 6908. (e) Kagan, H.B.; Riant, O. Chem. Rev., 1992, 92, 1007. (f) Lohray, B.B.; Bhushan, V. Angew. Chem., 1992, 104, 740. (g) Deloux, L.; Srebnik, M. Chem. Rev., 1993, 93, 673.

3. Van Gastel, F.J.C.; Klunder, A.J.H.; Zwanenburg, B. Recl. Trav. Chim. Pays-Bas, 1991, 110, 175.

4. Sharpless, K.B.; Amberg, W.; Bennani, Y.L.; Crispino, G.A.; Hartung, J.; Jeong, K.-S.; Kwong, H.L.; Morikawa, K.; Wang, Z.-M.; Xu, D.; Zhang, X.-L. J. Org. Chem., 1992, 57, 2768 and references cited therein.

5. For recent reviews on asymmetric dihydroxylation reaction, see: (a) Lohray, B.B. Tetrahedron: Asymm., 1992, 3, 1317. (b) Johnson, R.A.; Sharpless, K.B. Catalytic Asymmetric Dihydroxylation. In Catalytic Asymmetric Synthesis ; Ojima, I. Ed.; VCH Publishers: New York, 1993; 227. (c) Kolb, H.C.; 
VanNieuwenhze, M.S.; Sharpless, K.B. Chem. Rev., 1994, 94, 2483. (d) Balavoine, G.G.A.; Manoury, E. Appl. Organomet. Chem., 1995, 9, 199.

6. (a) Classon, B.; Liu, Z.; Samuelsson, B. J. Org. Chem., 1988, 53, 6126. (b) Liu, Z.; Classon, B.; Samuelsson, B. J. Org. Chem., 1990, 55, 4273.

7. (a) Sharpless, K.B.; Amberg, W.; Beller, M.; Chen, H.; Hartung, J.; Kawanami, Y.; Lübben, D.; Manoury, E.; Ogino, Y.; Shibata, T.; Ukita, T. J. Org. Chem., 1991, 56, 4585. (b) Morikawa, K.; Park, J.; Andersson, P.G.; Hashiyama, T.; Sharpless, K.B. J. Am. Chem. Soc., 1993, 115, 8463. (c) Crispino, G.A.; Makita, A.; Wang, Z.-M.; Sharpless, K.B. Tetrahedron Lett., 1994, 35, 543.

8. (a) Jeong, K.-S.; Sjö, P.; Sharpless, K.B. ibid., 1992, 33, 3833. (b) Soderquist, J.A.; Rane, A.M.; López, C.J. ibid., 1993, 34, 1893. (c) VanNieuwenhze, M.S.; Sharpless, K.B. ibid., 1994, 35, 843. (d) Ko, S.Y.; Malik, M.; Dickinson, A.F. J. Org. Chem., 1994, 59, 2570.

9. Wang, L.; Sharpless, K.B. J. Am. Chem. Soc., 1992, 114, 7568.

10. While this research was in progress Wang et al. published on the asymmetric dihydroxylation of a series of conjugated cyclic cis-disubstituted olefins that gave only moderate results with a few exceptions.

Wang, Z.-M.; Kakiuchi, K.; Sharpless, K.B. J. Org. Chem., 1994, 59, 6895.

11. (a) Fuji, K.; Tanaka, K.; Miyamoto, H. Tetrahedron Lett., 1992, 33, 4021. (b) Hanessian, S.; Meffre, P.; Girard, M.; Beaudoin, S.; Sancéau, J.-Y.; Bennani, Y. J. Org. Chem., 1993, 58, 1991.

12. Takano, S.; Yoshimitsu, T.; Ogasawara, K. ibid., 1994, 59, 54.

13. The ligand DHQD-IND is not commercially available. The synthesis of DHQD-IND was performed as described in the supplementary material of Ref. 9.

14. (a) Koch, H. Mh. Chem., 1962, 93, 1343. (b) Inukai, T.; Kasai, M. J. Org. Chem., 1965, 30, 3567. (c) Devine, P.N.; Oh, T. J. Org. Chem., 1992, 57, 396.

15. The synthesis of 3 and 7 was an improved version of the procedure of Ref. 14b and Ref. 14c. One equivalent of $\mathrm{AlCl}_{3}$ was added to a solution of diethyl fumarate or ethyl acrylate in benzene ( 500 $\mathrm{mL} / \mathrm{mol}$ ). The reaction vessel was equipped with a reflux condenser, cooled to $-80^{\circ} \mathrm{C}$ and directly connected to a gas cylinder containing 1,3-butadiene. Slowly condensing the gas while the reaction mixture was well stirred resulted in a slightly exothermal reaction. After $1.5 \mathrm{~h}$ the excess of 1,3-butadiene was allowed to evaporate. Then the reaction mixture was diluted with ethyl acetate and extracted with water $(3 \mathrm{x})$. The combined water layers were again extracted with ethyl acetate. The organic fractions were dried over $\mathrm{Na}_{2} \mathrm{SO}_{4}$ and concentrated in vacuo.

16. (a) Ver Nooy, C.D.; Rondestvedt Jr., C.S. J. Am. Chem. Soc., 1955, 77, 3583. (b) Van Tamelen, E.E.; Shamma, M. ibid., 1954, 76, 2315.

17. (a) Varech, D.; Jacques, J. Tetrahedron, 1972, 28, 5671. (b) Nakazaki, M.; Naemura, K.; Kondo, Y. J. Org. Chem., 1979, 44, 16. (c) Cervinka, O.; Kriz, O. Collection Czechoslov. Chem. Commun., 1968, 33, 2342. (d) Berson, J.A.; Remanick, A.; Suzuki, S.; Reynolds-Warnhoff, P.; Willner, D. J. Am. Chem. Soc, 1961, 83, 3986.

18. Kagan, H.B.; Fiaud, J.C. Top. Stereochem., 1988, 18, 249

19. (a) Lohray, B.B.; Bhushan, V. Tetrahedron Lett., 1993, 34, 3911. (b) VanNieuwenhze, M.S.; Sharpless, K.B. J. Am. Chem. Soc., 1993, 115, 7864. (c) Ward, R.A.; Procter, G. Tetrahedron Lett., 
1992, 33, 3363. (d) Crispino, G.A.; Makita, A.; Wang, Z.-M.; Sharpless, K.B. Tetrahedron Lett., 1994, 35, 543.

20. Hawkins, J.M.; Meyer, A. Science, 1993, 260, 1918.

21. Bazbouz, A.; Christol, H.; Coste, J.; Plénat, F. Bull. Soc. Chim. Fr., 1978, II, 305-311.

Acknowledgment. This investigation was supported by the Netherlands Foundation of Chemical Research (SON) with financial aid from the Netherlands Organization for Scientific Research (NWO).

(Received in UK 29 January 1996; revised 10 April 1996; accepted 12 April 1996) 